\title{
IMPLEMENTATION OF POLICIES FOR MICRO, SMALL AND \\ MEDIUM ENTERPRISES (UMKM) DEVELOPMENT IN INCREASING BUSINESS COMPETITIVENESS \\ (Study in Micro, Small and Medium Enterprises in Kendari City)
}

\author{
${ }^{1}$ Muh. Husriadi, ${ }^{2}$ Edy Yulianto and ${ }^{3} \mathrm{M}$. Kholid Mawardi \\ ${ }^{1}$ Master of Business Administration, Faculty of Administrative Sciences \\ Brawijaya University, Malang, Indonesia \\ ${ }^{2,3}$ Faculty of Administrative Sciences \\ Brawijaya University, Malang, Indonesia
}

\begin{abstract}
Purpose - This research aims to find out and explain the implementation of policies for the development of micro, small and medium enterprises (MSMEs) in improving business competitiveness in Kendari City and to describe the effectiveness of the policies for developing micro, small and medium enterprises (MSMEs) in increasing business competitiveness.

Design/methodology/approach - This research uses a narrative qualitative approach. Data collection techniques used are interviews, in-depth observation, and Snowball sampling.

Findings - The results of the research found that the implementation of policies realized through training programs in the effort to develop micro, small and medium enterprises (MSMEs) to have competitiveness was not maximized due to the lack of follow-up (evaluation) of the programs that had been implemented, the existence of MSMEs that have not gained understanding after participating in training such as financial report management, inadequate human resources (HR), no special expertise to conduct financial management assistance, and the absence of product service center.
\end{abstract}

Practical Implications - The effectiveness of the policies will determine the improvement of business competitiveness for micro, small and medium enterprises (MSMEs).

Originality/value - This research presents the case of the implementation of policies for the development of micro, small, and medium enterprises (MSMEs) in Kendari City, which might impact the improvement of the workers' business competitiveness.

Keywords Policies, MSMEs, Competitiveness.

Vol. 28, No. 01 April 2020

(C) Centre for Indonesian Accounting and Management Research

Postgraduate Program, Brawijaya University 
Paper Type Research paper (case study)

\section{Introduction}

Micro, small and medium enterprises (MSMEs) are an important sector in realizing national economic development. The big role of micro, small and medium enterprises (MSMEs) was also proven to save the nation's economy during the 1998 economic crisis (Rusdin, 2009). According to Tambunan (2009) the group of micro, small and medium enterprises (MSMEs) has provided many job opportunities compared with job opportunities provided by large companies.

In addition, the role of micro, small and medium enterprises (MSMEs) is very significant in creating employment opportunities and the added value has proven that MSMEs are able to provide social benefits that is reducing income inequality (Nugent and Yhee, 2002). When viewed in terms of business forms, micro, small and medium enterprises (MSMEs) are a form of community small business whose establishment is based on one's initiative. Even though its establishment is based on one's initiative, export micro, small and medium enterprises (MSMEs) contribute to the increase and as a subcontractor that provides various inputs for large scale businesses as well as sources of innovation (Sulistyastuti, 2004). In addition, the large contribution of MSMEs is also able to utilize various natural resources (SDA) that have the potential to be developed in an area that has not been processed commercially. Urata (2000) mentions that micro, small and medium enterprises (MSMEs) play several important roles in Indonesia, namely: (1) MSMEs major players in economic activity in Indonesia, (2) Providers of employment opportunities, (3) Important players in local economic development and community development, (4) Market creator and innovation through its flexibility and sensitivity as well as dynamic linkages between company activities, and (5). Contribute to an increase in non-oil exports.

Although micro, small and medium enterprises (MSMEs) can be said to be able to have the resilience of the global crisis turmoil, in reality the problems faced are very complex. According to Abor, (2010), the development of micro, small and medium enterprises (MSMEs) is always limited by a number of factors such as, lack of access to appropriate technology, limited access to markets, the existence of laws, regulations and regulations that hinder the development of the micro business sector, small 
and medium enterprises (MSMEs), weak institutional capacity and lack of management and training skills. Therefore, micro, small and medium enterprises (MSMEs) need to get serious attention in terms of empowerment so that they can develop. According to Nurjannah (2014) efforts taken to develop micro, small and medium enterprises (MSMEs) are to improve the ability of micro, small and medium enterprises (MSMEs) to access sources of financing that is increasing the quantity and quality through entrepreneurship training, increasing the quantity and quality of services financing for micro, small and medium enterprises (MSMEs), providing facilities and support for financial institutions in providing financing services for micro, small and medium businesses (MSMEs). Looking at the various roles and contributions as well as the problems faced by micro, small and medium enterprises (MSMEs) in the process of business continuity, micro, small and medium enterprises (MSMEs) need policy instruments that can be used to support the development of micro, small and medium businesses (MSME).

\section{Problem Formulation}

1. How is the implementation of policies for developing micro, small and medium enterprises (MSMEs) in improving business competitiveness in the city of Kendari?

2. How is the effectiveness of implementing micro, small and medium enterprise (MSMEs) business development policies in improving business competitiveness?

\section{Research Purpose and Objectives}

1. Knowing and explaining the implementation of policies for developing micro, small and medium enterprises (MSMEs) in improving business competitiveness in the city of Kendari.

2. Knowing and explaining the effectiveness of implementing micro, small and medium enterprise (MSME) business development policies in improving business competitiveness in the city of Kendari.

\section{Theory Study}

\subsection{Micro, Small and Medium Enterprises (MSMEs)}

According to Law No. 20 of 2008 concerning micro, small and medium enterprises (MSMEs), the definition of Micro Business is a productive business for individuals and / or individual business entities that meet the criteria for micro business (UM). Small-scale business (UK) is a productive economic business that stands alone, which is carried out by individuals or business entities that are not subsidiaries or non-branch companies that are 
owned, controlled, or become either directly or indirectly part of mediumsized businesses (UM). Medium Enterprise (UM) is a productive economic business that stands alone, which is carried out by individuals or business entities that are not subsidiaries or branch companies that are owned, controlled, or become a part either directly or indirectly with a small (UK) or large business with the amount of net worth or the results of annual sales.

\subsection{Policy Implementation}

According to Fatih (2010) policy implementation is a good and correct implementation of the program in order to achieve policy objectives. According to Meter (1975) the implementation of policies, as actions carried out either by individuals or officials or government or private groups directed at achieving the objectives outlined in the policy decision.

\subsection{Effectiveness}

According to Effendy (1989), the effectiveness is communication that the process to achieve planned goals in accordance with budgeted costs, the time set and the number of personnel determined. Whereas according to Susanto (1975:156) effectiveness is the message power to influence or the level of the ability of messages to influence. According to Weiss (1972), the size of program effectiveness can be measured using 5 main elements in the program evaluation model, among others, program objectives, program objectives, program socialization, appropriate management and guidance, program monitoring.

\section{Research Methods}

\subsection{Types of research}

In this study, the author uses a type of narrative qualitative research that is about a series of events related to human experience (Creswell, 2015). Data collection is done by in-depth interviews, observations to participants and snowball sampling techniques. The researcher seeks to describe, describe and interpret the problem and then draw conclusions from the problem regarding the implementation of the policy of developing micro, small and medium enterprises (MSMEs) in increasing business competitiveness in Kendari City.

\subsection{Research Focus}

The focus of research is the things that are the center of attention in research so that it will facilitate research to determine which data is needed for a study. Therefore, the focus of the research is the implementation, 
effectiveness, and impact of the development policies of micro, small and medium enterprises (MSMEs) in enhancing business competitiveness in Kendari City, which includes:

a. The implementation of the policy of developing micro, small and medium enterprises (MSMEs) in enhancing business competitiveness includes the program model used to solve the problems of small and medium micro enterprises (MSMEs).

b. The effectiveness of the implementation of micro, small and medium enterprises (MSME) development policies in enhancing business competitiveness include:

1) Program objectives

2) Program objectives

3) Program socialization

4) Management and guidance

5) Program monitoring

\title{
5.3 Research Sites
}

This research was conducted in Kendari City, with the target of the research object being micro and small business owners (MSMEs) who had been registered with the Kendari City Trade, Cooperative and MSME Office.

\subsection{Research Informants}

Informants in this study were (1) Head of the Kendari City Trade, Cooperative and MSME Office (2) Head of Kendari City Trade, Cooperatives and MSMEs (3) Micro, Small and Medium Enterprises (MSME) Players.

\subsection{Research Instruments}

The instrument used by researchers in collecting data related to the implementation of policies for the development of micro, small and medium enterprises (MSMEs) in improving business competitiveness, namely observation, interviews, and documentation:

a. Observation

In this study, observations were made related to the implementation of the policy of developing micro, small and medium enterprises (MSMEs) in enhancing business competitiveness in Kendari City. The researcher observes and also interacts with business actors directly. Researchers also make observations and go directly to the field.

\author{
Vol. 28, No. 01 April 2020 \\ (C) Centre for Indonesian Accounting and Management Research \\ Postgraduate Program, Brawijaya University
}


b. Interview

In this study, researchers used semi-structured interview methods. The researcher asked questions spontaneously and heard the opinions of the informants more. The question that was asked even though it was spontaneous but must be as offensive as possible related to the problem formulation.

c. Documentation

The data needed is related to the implementation of policies for the development of micro, small and medium enterprises (MSMEs) in increasing business competitiveness in Kendari City in the form of documents or reports from previous researchers. Record the documents owned by the Kendari City Trade, Cooperative and UMKM Office as well as community participation and so on as secondary data to support research.

\section{Data collection and Data Analysis Techniques}

Kendari City as the capital of Southeast Sulawesi province has a land area of $295.89 \mathrm{Km} 2$ or 0.78 percent of the land area of Southeast Sulawesi Province. Currently the city of Kendari consists of 10 districts and 64 villages with a population of 359,371 inhabitants. This condition is an opportunity for the growth and development of business actors, especially micro, small and medium enterprises (MSMEs), which until now has recorded 10862 business units in micro, small and medium scale. Based on data from the Department of Commerce, Cooperatives and SMEs in the city of Kendari, the number of micro, small and medium enterprises (MSMEs) based on business classification in the city of Kendari can be seen in the following table.

Table 5.1 Data on the Number of MSMEs in Kendari City in (2018)

\begin{tabular}{|c|c|c|c|c|}
\hline \multirow{2}{*}{ City } & \multicolumn{3}{|c|}{ Business Criteria } & \multirow{2}{*}{ amount } \\
\cline { 2 - 4 } & $\begin{array}{c}\text { Micro } \\
\text { (unit) }\end{array}$ & $\begin{array}{c}\text { Small } \\
\text { (unit) }\end{array}$ & $\begin{array}{c}\text { Medium } \\
\text { (unit) }\end{array}$ & \\
\hline Kendari & 8498 & 1897 & 467 & 10862 \\
\hline
\end{tabular}

Source: Department of Industry and Commerce of Kendari City (2018)

In the table, it can be seen that the number of micro, small and medium enterprises (MSMEs) in the city of Kendari is 10862 business actors consisting of 8498 micro businesses, 1897 small businesses and 467 medium businesses. With this amount it can be said that the role and contribution of micro, small and medium enterprises (SMEs) in the city of 
Kendari is very large on the economy of Kendari. Seeing the number of businesses in the city of Kendari, including in the service sector, trade and industry, it is very appropriate if the city of Kendari earned the nickname of the forefront of the economy of Southeast Sulawesi (Southeast Sulawesi). If the superior potential of these businesses is developed and managed with a strong commitment by the Kendari city government especially the Industry, Trade, Cooperatives and SMEs Office of the city of Kendari it will provide great benefits for the Kendari city government and the people of this city in advancing revenue and level economy.

In addition, the number of MSMEs in the city of Kendari can also be seen by district. This can be seen in table 5.4 below;

Table 5.2 Data on the number of MSMEs in Kendari City based on District in (2018)

\begin{tabular}{|c|c|c|c|c|c|}
\hline \multirow[b]{2}{*}{ No } & \multirow[b]{2}{*}{ Districts } & \multicolumn{3}{|c|}{ Business Criteria } & \multirow[b]{2}{*}{ amount } \\
\hline & & $\begin{array}{l}\text { Micro } \\
\text { (unit) }\end{array}$ & $\begin{array}{l}\text { Small } \\
\text { (unit) }\end{array}$ & $\begin{array}{c}\text { Medium } \\
\text { (unit) }\end{array}$ & \\
\hline 1 & Mandonga & 4244 & 375 & 11 & 4630 \\
\hline 2 & Baruga & 201 & 102 & 9 & 312 \\
\hline 3 & Puuwatu & 672 & 106 & 14 & 792 \\
\hline 4 & Kadia & 231 & 221 & 25 & 477 \\
\hline 5 & Wua-wua & 293 & 257 & 42 & 592 \\
\hline 6 & Poasia & 894 & 176 & 38 & 1108 \\
\hline 7 & Abeli & 283 & 96 & 7 & 386 \\
\hline 8 & Kambu & 596 & 356 & 40 & 992 \\
\hline 9 & Kendari & 295 & 123 & 272 & 690 \\
\hline 10 & $\begin{array}{l}\text { Kendari } \\
\text { Barat }\end{array}$ & 789 & 85 & 9 & 883 \\
\hline & Total & 8498 & 1897 & 467 & 10862 \\
\hline
\end{tabular}

Source: Department of Industry and Commerce of Kendari City (2018)

In the table, it can be seen that the number of micros, small and medium enterprises (MSMEs) in Kendari City is 10862 business actors consisting of 8498 micro businesses, 1897 small businesses, and 467 medium businesses. With this number, it can be said that the role and contribution of micro, small and medium enterprises (MSMEs) in Kendari City is very large on the economy of Kendari City.

\section{Results}




\subsection{Overview of Micro, Small and Medium Enterprises (MSMEs) in the city of Kendari}

Kendari City is the capital of Southeast Sulawesi province, as an astronomical line the city is located in the southern part of the equator which is between 3054'40" and 405'05 " South Latitude (LS) and extends widely from West to East between 122o26'33 " and 122o39'14 " East Longitude (BT).

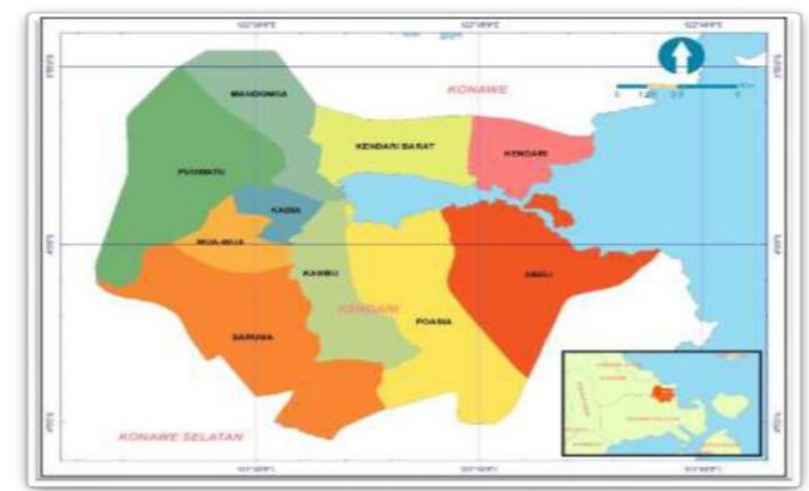

Figure 4.1. Map of Kendari city area

Source: BPS of the city of Kendari, processed by researchers (2018).

When viewed from its geographical location, in the north the city is bordered by Konawe Regency, then in the south it borders South Konawe Regency, in the east it borders the Kendari sea, and in the west it borders South Konawe Regency. The total land area of the city is $295.89 \mathrm{Km} 2$ or around 0.78 percent of the land area of Southeast Sulawesi province. At present, the area according to the Subdistrict is also very diverse, including Poasia sub-district is the most extensive sub-district $(18.76 \%)$ of Kendari city area which consists of 4 (four) sub-districts, then Baruga Sub-district (16.61\%) consisting of 4 (four) kelurahan, Abeli District (15.88\%) consisting of 13 (thirteen) kelurahan, Puuwatu District (15.48\%) consisting of 6 (six) kelurahan, Mandonga District (7.88\%) consists of 6 (six) villages, West Kendari District $(7.57 \%)$, consisting of 9 (nine) villages, Kambu District (7.15\%) consisting of 4 (four) villages, Kendari District (4.80) \%) consisting of 9 (nine) villages, Wua-Wua District (3.29\%) consisting of 4 (four) villages, and Kadia District (2.57\%) consisting of 5 (five) villages. 


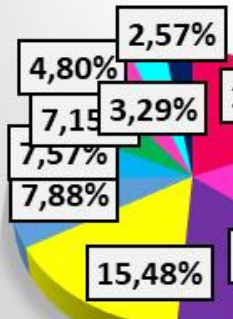

$15,88 \%$

\section{Kecamatan}

Poasia

- Baruga

Abeli

Puuwatu

- Mandonga

Kendari Barat

Figure 4.2. Percentage of Area in Kendari City by District (2018)

Source: BPS of the city of Kendari, processed by researchers (2018).

Kendari City as the capital of Southeast Sulawesi province has a land area of $295.89 \mathrm{Km} 2$ or 0.78 percent of the land area of Southeast Sulawesi Province. Currently the city of Kendari consists of 10 districts and 64 villages with a population of 359,371 inhabitants. This condition is an opportunity for the growth and development of business actors, especially micro, small and medium enterprises (MSMEs), which until now has recorded 10862 business units in micro, small and medium scale. Based on data from the Department of Commerce, Cooperatives and SMEs in the city of Kendari the number of micro, small and medium enterprises (MSMEs) based on business classification in the city of Kendari can be seen in the following table.

Table 5.3: Data on the number of MSMEs in Kendari City in 2018

\begin{tabular}{|c|r|r|r|r|}
\hline \multirow{2}{*}{ City } & \multicolumn{3}{|c|}{ Business Criteria } & \multirow{2}{*}{ total } \\
\cline { 2 - 4 } & $\begin{array}{c}\text { Micro } \\
\text { (unit) }\end{array}$ & $\begin{array}{c}\text { Small } \\
\text { (unit) }\end{array}$ & $\begin{array}{c}\text { Intermediate } \\
\text { (unit) }\end{array}$ & \\
\hline Kendari & 8498 & 1897 & 467 & 10862 \\
\hline
\end{tabular}

Source: Disperindag Kendari city (2018). 
In this table, it can be seen that the number of micro, small and medium enterprises (MSMEs) in the city of Kendari is 10862 business operators consisting of 8498 micro businesses, 1897 small businesses and 467 medium businesses. With this amount it can be said that the role and contribution of micro, small and medium enterprises (SMEs) in the city of Kendari is very large on the economy of Kendari. Seeing the number of businesses in the city of Kendari, including in the service sector, trade and industry, it is very suitable if the city of Kendari earned the nickname of the forefront of the economy of Southeast Sulawesi (Southeast Sulawesi). If this superior potential of these businesses is developed and managed with a strong commitment by the Kendari city government especially the Industry, Trade, Cooperatives and SMEs Office of the city of Kendari it will provide great benefits for the Kendari city government and the people of this city in advancing revenue and level economy.

With its strategic condition and location, the city has increased regional economic growth due to the presence of micro, small and medium enterprises (MSMEs). Thus the Kendari city government must pay attention and maintain as well as improve facilities for micro, small and medium enterprises (MSMEs) in each region (kelurahan and kecamatan) and this can be seen from the number of micro, small and medium businesses (MSMEs) that in this city. Therefore the number of MSMEs in the city of Kendari can also be seen by district. This can be seen in table 5.4 below;

Table 5.4: Data on the number of MSMEs in Kendari city by district in

\begin{tabular}{|c|c|c|c|c|c|}
\hline \multirow[b]{2}{*}{ No } & \multirow[b]{2}{*}{ Sub-district } & \multicolumn{3}{|c|}{ Business Criteria } & \multirow[b]{2}{*}{ total } \\
\hline & & $\begin{array}{l}\text { Micro } \\
\text { (unit) }\end{array}$ & $\begin{array}{l}\text { Small } \\
\text { (unit) }\end{array}$ & $\begin{array}{l}\text { Intermediate } \\
\text { (unit) }\end{array}$ & \\
\hline 1 & Mandonga & 4244 & 375 & 11 & 4630 \\
\hline 2 & Baruga & 201 & 102 & 9 & 312 \\
\hline 3 & Puuwatu & 672 & 106 & 14 & 792 \\
\hline 4 & Kadia & 231 & 221 & 25 & 477 \\
\hline 5 & Wua-wua & 293 & 257 & 42 & 592 \\
\hline 6 & Poasia & 894 & 176 & 38 & 1108 \\
\hline 7 & Abeli & 283 & 96 & 7 & 386 \\
\hline 8 & Kambu & 596 & 356 & 40 & 992 \\
\hline 9 & Kendari & 295 & 123 & 272 & 690 \\
\hline 10 & Kendari Barat & 789 & 85 & 9 & 883 \\
\hline & e. Disnerind & dari citv & & 467 & 10862 \\
\hline
\end{tabular}

Source: Disperindag Kendari city (2018). 
The table is data on the number of micro, small and medium enterprises (MSMEs) in the city of Kendari by subdistrict in 2018. It can be seen that in this city there are still many micro scale businesses rather than small scale ones. The largest number of micro, small and medium enterprises (MSMEs) is in Mandonga subdistrict with 4,244 micro, small and medium enterprises (MSMEs) and the lowest is in Baruga districts with 201 micro, small and medium businesses (MSMEs).

\subsection{Implementation of Micro, Small and Medium Enterprises (MSME) Development Policies in Improving Business Competitiveness}

The city of kendari is the capital of the province of Southeast Sulawesi which has the dynamics of change, opportunities and challenges in the future, especially in the micro, small and medium enterprises (MSME) sector. The presence of policies that are right on target, it is needed. Efforts to develop micro, small and medium enterprises (MSMEs) in the city of Kendari so that they have competitiveness to be able to compete, the Kendari city government made several policies for developing micro, small and medium businesses (MSMEs) as revealed by research informants (A1) namely, as follows:

"The form of micro, small and medium enterprise (MSME) business development policy in the city of Kendari has been regulated in regional regulation (perda) number 1 of 2018 concerning the protection and development of the creative economy, namely financing and capital facilitation policies; product marketing and promotion support; and ease of business licensing. With this policy, it is hoped that the skills of MSMEs can be helped so that they can have high competitiveness in order to compete "(Interview: Thursday, November 8, 2018).

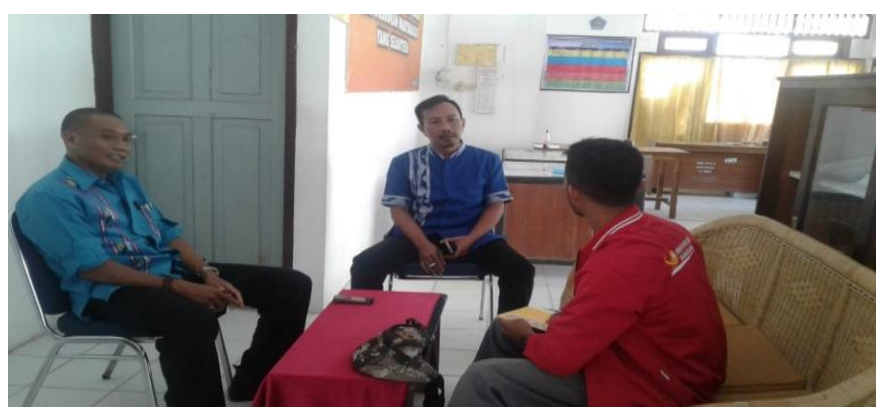

Figure 4.3 Researcher's interview with the head of the Department of Industry, Trade, Cooperatives and SMEs in the

Vol. 28, No. 01 April 2020

(C) Centre for Indonesian Accounting and Management Research Postgraduate Program, Brawijaya University 
Based on the results of these interviews, it can be seen that there are 3 policy points for developing micro, small and medium enterprises (SMEs) in the city of Kendari in an effort to support the competitiveness of micro, small and medium businesses (MSMEs) to be able to compete. Thus the policy of developing micro, small and medium enterprises (MSMEs) has been regulated in regional regulation (perda) number 1 of 2018 concerning protection and development of the creative economy, namely the first policy of financing and capital facilitation; both product marketing support and promotion policies; as well as three business licensing ease policies. Therefore, with this policy, it is expected that the capabilities of micro, small and medium enterprises (MSMEs) can increase and have competitiveness so that they can compete.

To formulate an appropriate micro, small and medium enterprise (MSME) business development policy, the Kendari city government in this case the Kendari City Office of Trade, Cooperatives and MSMEs as facilitators of city government affairs in the trade, cooperative and MSME sectors based on the principle of autonomy which becomes the authority and task deconcentration and assistance in formulating policies have adjusted to the strategic plan (Renstra) to develop the micro, small and medium enterprises (SMEs) sector in the city of Kendari. Therefore, the form of implementation of the policy of developing micro, small and medium enterprises (SMEs) in the city of Kendari is realized through training programs. To find out the extent of the use of training programs in spurring the understanding and skills of micro, small and medium enterprises (MSMEs) in order to have competitiveness, a good implementation process is needed so that they can be felt by micro, small and medium businesses (MSMEs). Therefore the results of researcher interviews with research informants (A1) reveal that:

"All this time our training has been carried out, but indeed there are still shortages, especially in the financial management sector, it is still difficult for us to provide an understanding of financial management specifications because our employees are not experts in the field while bringing in proficient material in the field. If we have done the facilitation to the bank to obtain business credit, we have done it first, we do the socialization first by inviting BRI banks to KUR socialization, then we teach how to make a proposal for financial assistance to non-bank institutions. after that we facilitate facilitation of business capital loans, while if the banks continue to use collateral and banks also 
rarely provide capital loans if micro, small and medium enterprises (MSMEs) have not been able to manage bookkeeping because banks ask for their business financial statements. And that's why we do specific training ation of financial management but the training that we did was indeed again understandable that we could not have more effect for micro, small and medium enterprises (MSMEs). Meanwhile, for ease of business licensing, it has been regulated in the mayor's regulation on micro and small business licensing in the sub-district "(Interview: Thursday, November 8, 2018).

Based on the description of the results of interviews conducted by researchers that the training of UMKM development has been carried out but it is still not maximal in the financial management sector because the human resources (HR) at the Department of Trade, Cooperatives and SMEs in Kendari city are still inadequate and do not have special expertise to assist financial management whereas to bring experts in the field of financial management the cost is very expensive. While the facilitation process to financial institutions is carried out by inviting the bank to socialize capital loans. Whereas in terms of ease of business licensing for micro and small business actors, it is delegated to the local sub-district where the business actors are located. It is also in accordance with the regulations of the mayor of Kendari. Furthermore, the research informant (A2) revealed as follows:

"So far, the training has been carried out although there are a number of micro, small and medium enterprises (MSMEs) entrepreneurs who are not present in the training that we have held, so not all who participated were micro, small and medium businesses (MSMEs). but we will continue to try to invite them to participate in trainings that also benefit them. We conduct technical packaging and design specifications training, business management and marketing technical training. If the technical training on packaging specifications and design is indeed still difficult, yes, making packaging designs should be good because our employees also don't understand how to make packaging designs. And if for marketing we help through events, and exhibitions. However, in terms of infrastructure, I admit that it is still lacking in the central locations of the products of micro, small and medium enterprises (MSME) entrepreneurs so that the products produced by micro, small and medium enterprises (MSMEs) cannot be widely known because they are still sold at their home, there is no central place that holds their products. And

Vol. 28, No. 01 April 2020

(C) Centre for Indonesian Accounting and Management Research Postgraduate Program, Brawijaya University 
this is indeed our weakness "(Interview: Thursday, November 8, 2018).

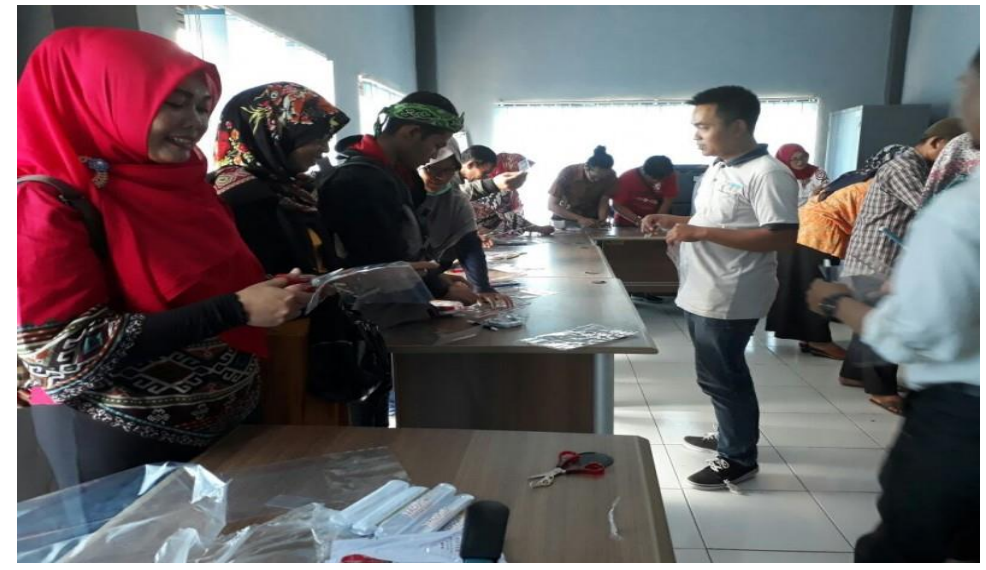

Gambar 4.4 Pelatihan Desain Kemasan (2018)

Based on the description from the research informant (A2) above, it illustrates that the accuracy of the trainings has not been going well carried out by the Office of Commerce, Cooperatives and SMEs of the city of Kendari because there are still micro, small and medium-sized businesses (MSMEs) that have not participated in the training. held.

In addition, the packaging design aspect is still not maximal because human resources (HR) in the Kendari City Department of Trade, Cooperatives and SMEs are still inadequate. As for the marketing aspect of the Kendari City Department of Trade, Cooperatives and SMEs, acknowledging that there is still no ole-ole center for micro, small and medium enterprises (MSMEs) to market the products that have been produced so that researchers conclude that training implementation has not been maximized. The same thing was revealed by research informant (B) namely:

"I used to take part in an exhibition organized by the city government (Pemkot) and the training as well, but I did not understand how to use the application. In the past packaging design, I participated too, I was taught how to make product stickers, but at the moment there is no more training. For business licensing, I take care of it in the sub-district office "(Interview: Thursday, November 8 2018). 
The informant further $(\mathrm{C})$ revealed

"I used to take part in the activity and I think the material is pretty good for example making plastic packaging design and how to write product logos and also a lot of business motivation but after the training is finished we are not invited anymore for evaluation" Interview: Thursday, November 8 2018).

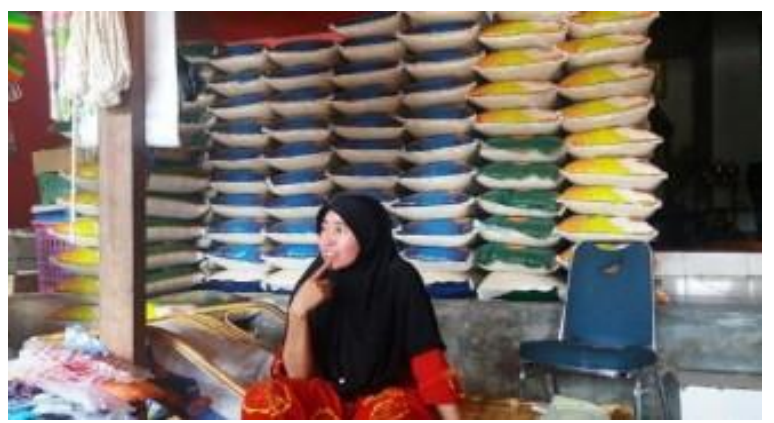

Gambar 4.5 Wawancara peneliti dangan pelaku usaha sembako (2018)

Based on the results of interviews from several informants consisting of the head of the Department of Commerce, Cooperatives and SMEs in the city of Kendari, and Kasi. The development and development of Kendari city SMEs, as well as the micro, small and medium business actors above, illustrates that the implementation of policies realized through training programs in the effort to develop micro, small and medium enterprises (MSMEs) in order to have competitiveness has been carried out by the Department of Trade, Cooperatives and SMEs in the city of Kendari, but in its implementation is still not optimal. Researchers found that the implementation of the program in an effort to develop micro, small and medium enterprises (MSMEs) in order to have competitiveness is still not optimal because there is no follow up (evaluation) of the programs that have been implemented, there are still micro, small and medium business actors (MSMEs) that have not yet gained understanding after participating in training, for example management of financial statements, are still inadequate of human resources (HR) at the Department of Commerce, Cooperatives and MSMEs of the city of Kendari and have special expertise to provide financial management assistance, and there is no central medical center. -By for products produced by micro, small and medium enterprises (MSMEs).

\subsection{Effectiveness of the Implementation of Micro, Small and Medium Enterprises (MSME) Development Policies in Increasing Business Competitiveness}

Vol. 28, No. 01 April 2020

(C) Centre for Indonesian Accounting and Management Research Postgraduate Program, Brawijaya University 
In measuring the effectiveness of implementing micro, small and medium MSME business development policies in the city of Kendari researchers have five elements that are used as a reference in interviewing research informants namely, among others, program objectives, program objectives, program socialization, management and coaching, and monitoring.

\section{1) Program Objectives}

Kendari City's Office of Trade, Cooperatives and SMEs has the aim of meeting the needs of micro, small and medium enterprises (MSMEs) in this city. However, it seems that the goal has not been reached and is maximally realized as the results of the interview of researchers with research informants (A1) are as follows:

"The purpose of this program is the creation of an increase in the economy of the urban area of kendari through empowerment and development of micro, small and medium enterprises (MSMEs), which consists of several points, namely (1) increasing community participation and the business world to develop the Creative Economy; (2) increase productivity, competitiveness and market share of the Creative Industries; (3) increase access to productive resources; (4) increasing access to capital; (5) increase the soul of creativity; (6) enhance partnerships and Creative Business Networks; and (7) provides protection for localbased creative industry businesses. Therefore, in order to achieve this target, we have established programs for example, facilitating micro, small and medium enterprises (MSMEs) to be able to get access to business financing, making it easy to administer SIUP for micro and small businesses and marketing access to market products. products that have been produced even though all of them have not been implemented but we are still trying. While the new one was implemented in terms of product packaging. There are already a number of micro, small and medium enterprises (MSMEs) that have participated in training on design, the packaging has started to be good. It's just that in financial accounting, not all micro, small and medium enterprises (MSMEs) understand even though they have participated in training several times that we have held with the bank, but we try to continue to provide assistance to them ". (Interview: Monday 12 November 2018).

Vol. 28, No. 01 April 2020

(C) Centre for Indonesian Accounting and Management Research Postgraduate Program, Brawijaya University 
Something similar was added by the research informant (A1), which is as follows:

"For the implementation of the program, we have carried out although not all of the programs have shown good results, but we continue to try to assist these micro, small and medium enterprises (MSMEs). For reasons for not producing good results, our employees also don't have much experience in assisting "(Interview: Monday 12 November 2018).

From the interviews conducted by researchers to the two informants above, it shows that the objectives of the Kendari City Department of Commerce, Cooperatives and SMEs program have been carried out, although not all programs have been implemented so that the researchers draw conclusions that the programs carried out by the Department of Trade, Cooperatives and SMEs Kendari city has not given maximum results (not yet effective). This is because there are still programs that have not been effectively realized, such as the existence of micro, small and medium enterprises (MSMEs) that have not been able to manage business financial accounting. In addition, there is still a lack of knowledge from a number of employees of the Department of Commerce, Cooperatives and SMEs in the city of Kendari to provide intensive assistance.

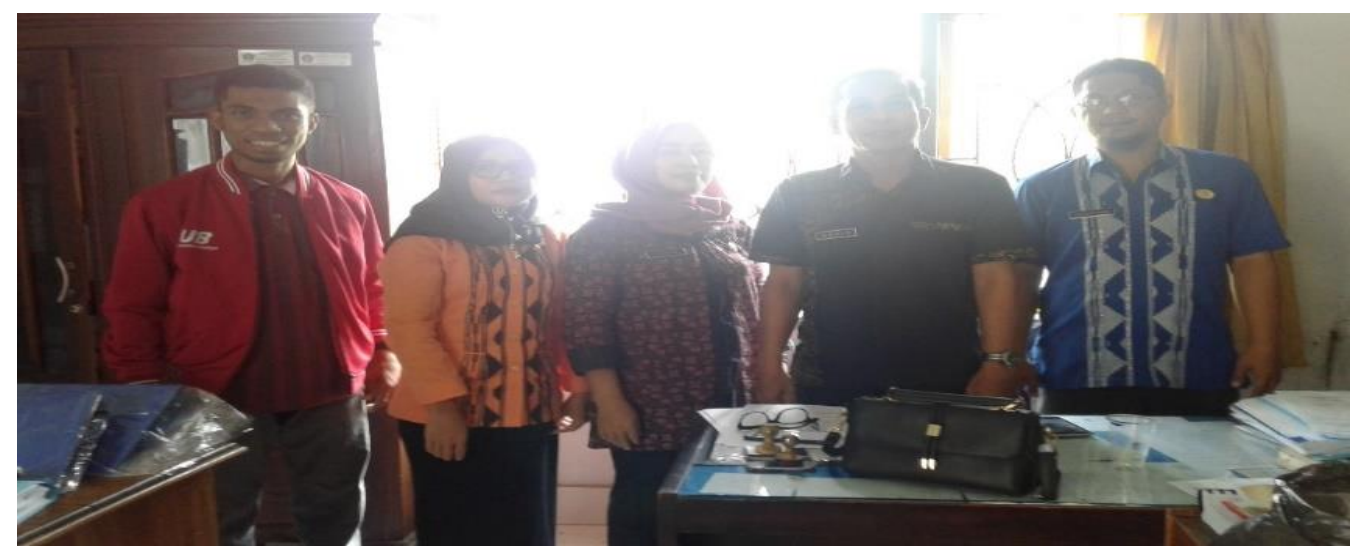

Figure 4.6 Researcher's interview with Kasi. Development and Development of Kendari city SMEs (2018)

\section{2) Program Objectives}

In implementing the program, it certainly has the targets and targets referred to by the authors in this study are targets that have become targets of the preparation of programs 
conducted by the Department of Commerce, Cooperatives and SMEs in the city of Kendari. To find out the program targets referred to by the Department of Commerce, Cooperatives and SMEs of Kendari city, in conducting the program implementation as in the interview conducted by researchers to the research informant (Al) about the question who are the targets of the training program conducted by the Department of Trade, Cooperatives and SMEs Kendari city Kendari city all this time? The answer to that question is as follows:

The same thing was conveyed by the informant (A1) about the same questions, namely as follows:

"So far the target of the program itself has been centered on micro, small and medium enterprises (MSMEs) that have been recorded and who have permanent businesses" (Interview: Monday 12 November 2018).

Based on the results of researchers' interviews conducted with research informants related to program targets, it shows that up to now the targets of the program are micro, small and medium enterprises (MSMEs) that have been recorded and have a permanent business so that with the existence of training programs by in the Department of Commerce, Cooperatives and SMEs in the city of Kendari it is very easy to distribute information.

\section{3) Program socialization}

Program socialization is a way for the program to be delivered to micro, small and medium enterprises (MSMEs) so that micro, small and medium enterprises (MSMEs) get information about the existence of business development programs. This situation is a strong basis for the establishment of a partnership between the Department of Trade, Cooperatives and SMEs in the city of Kendari with micro, small and medium enterprises (MSMEs). Therefore, the socialization must be integrated and carried out continuously so that micro, small and medium enterprises (MSMEs) are able to understand how the procedures of the program itself. As the interview results revealed by the informant (A1) on the question how is the socialization of the program conducted by the Department of Trade, Cooperatives and SMEs in the city of Kendari in the development of SMEs so far in the city of Kendari? The answer to that question is as follows:

The same thing was conveyed by informants (A2) about the same questions, namely as follows: 
"The socialization that we have carried out so far is still not going well because there is still a sectoral ego between the related agencies so that the micro, small and medium business (MSME) entrepreneurs are confused about participating in training, which must be attended to, sometimes the training held collides with the department others "(Interview: Monday 12 November 2018).

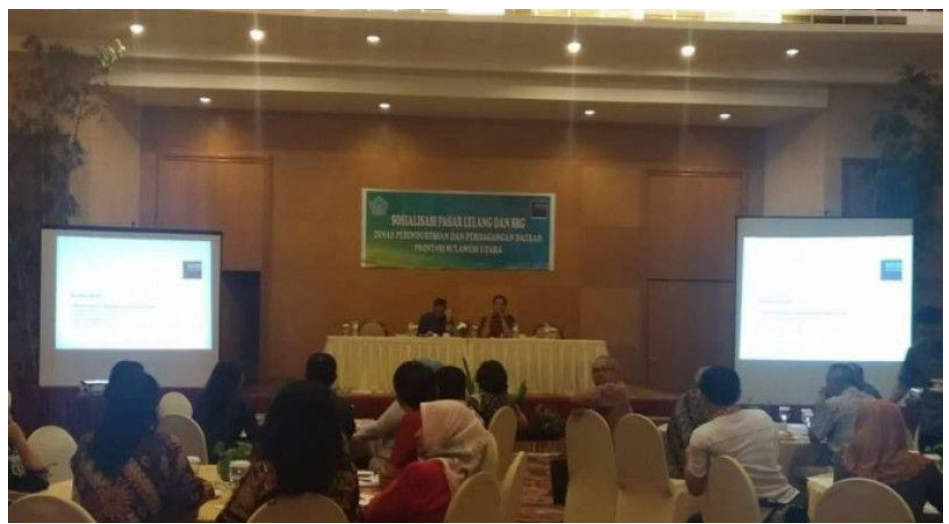

Figure 4.7 Program socialization by the Department of Industry, Trade, Cooperatives and SMEs in the city of Kendari (2018)

The research illustrates that the program socialization conducted by the Department of Trade, Cooperatives and SMEs of Kendari city has not been going well so far. This is because there are still constraints, namely there is still a sectoral ego between agencies related to the micro, small and medium enterprise development program (UMKM) in the city of Kendari so that the micro, small and medium business (MSME) entrepreneurs are confused following the training. sometimes it must be followed by training organized by the relevant department in conjunction with other agencies.

\section{4) Management and Coaching}

The accuracy of the coaching and management process carried out by the Kendari Department of Trade, Cooperatives and SMEs in the planning, distribution, coaching and reporting of the program is so important to be done as interviews conducted by researchers to research informants (A1) about the question how the effectiveness of the coaching and management process is conducted by the Office of Commerce, Cooperatives and SMEs of the city of Kendari to micro, small and medium enterprises (MSMEs) so far? The answer to that question is as follows: 
"For management and coaching indeed, I feel that we ourselves have not yet done the maximum because our human resources are also not able to carry out routine coaching because our employees themselves still do not understand how to provide assistance because it is not their field" (Interview: Monday 12 November 201 ).

The same thing was said by informant (A2), which is as follows:

"The management we have done so far has not been going well because we are also still lacking experts to provide assistance to micro, small and medium enterprises (MSMEs)" (Interview: Monday 12 November 2018).

Based on the results of interviews obtained from the two research informants above, it gives a description that the management and coaching conducted by the Department of Commerce, Cooperatives and SMEs of the city of Kendari is still not effective because there is still a lack of understanding of the human resources (HR) owned by the Trade Office , Cooperatives and SMEs of the city of Kendari to conduct regular coaching. In addition, there is still a lack of experts in providing direct assistance to micro, small and medium enterprises (MSMEs).

\title{
5) Program monitoring
}

Program monitoring is important because if the program implementation differs from the plan, monitoring can identify where the problem lies and then find a solution. Program monitoring is also generally carried out by collecting data / information on a regular and ongoing basis that produces development and achievement indicators so that the results are very useful for assessing whether a program / policy is implemented according to plan and whether the objectives set can be achieved. As the results of interviews by researchers to research informants (A1) related to the question how is the effectiveness of program monitoring conducted by the Department of Commerce, Cooperatives and SMEs in the city of Kendari in the development of micro, small and medium enterprises (MSMEs) so far in the city of Kendari? The answer to this question is as follows:

\begin{abstract}
"The monitoring we have done so far is collaborating with relevant agencies to see data on business growth. In addition, we also see from the growth of micro, small and medium enterprises (MSMEs) businesses that are in accordance with the indicators that we have determined.
\end{abstract}


Indeed, we are conducting this monitoring, we still look at the data not yet in the process of seeing directly which businesses have grown well "(Interview: Monday 12 November 2018).

The same thing was revealed by research informants (A2), which are as follows:

"So far we have been monitoring by collaborating with various parties including related agencies and banks" (Interview: Monday 12 November 2018).

From the results of interviews conducted by researchers to research informants illustrates that the monitoring carried out by the Department of Commerce, Cooperatives and SMEs of the city of Kendari is by collaborating with related agencies. However, it is still focused on the vision of the report in terms of growth data not yet on the process of seeing directly the business development of micro, small and medium enterprises (MSMEs) in the field so that researchers draw conclusions that the monitoring conducted by the Department of Commerce, Cooperatives and SMEs in the city of Kendari is still it has not been maximally carried out because it is still conducting monitoring which only looks at the growth data only, not yet the process of looking directly at developments in the field.

In analyzing the researchers only interviewed two research informants as the organizers of the program and they were considered by the researchers to provide information on the effectiveness measures which included the five aspects above. In terms of the effectiveness of the micro, small and medium enterprise (MSME) development program, it has met the criteria, but the implementation still has obstacles. Constraints in implementing the program can be in the form of inappropriate implementation of the plan and the results obtained. For this reason, there is a need for ongoing socialization about the program so that the program is able to meet the desired goals in realizing the effectiveness of implementation by having a good impact on business development.

\title{
7.4 The Impact of Implementing Micro, Small and Medium Enterprises (MSME) Development Policies in Increasing Business Competitiveness
}

The policy of the Kendari City Department of Trade, Cooperatives and SMEs in the micro, small and medium business sector (UMKM) is to be empowered and have a competitive edge, which is trying to improve the

\author{
Vol. 28, No. 01 April 2020 \\ (C) Centre for Indonesian Accounting and Management Research \\ Postgraduate Program, Brawijaya University
}


competitiveness of micro, small and medium enterprises (MSMEs) better. That effort is realized through programs that have been formulated so that with these programs micro, small and medium enterprises (MSMEs) can grow into sustainable businesses with greater orientation. Therefore, the program carried out by the Kendari City Department of Trade, Cooperatives and SMEs has an impact that can improve the quality of micro, small and medium business (MSME) entrepreneurs. The real impact of the implementation of the program on the development of micro, small and medium enterprises (MSMEs) felt by micro, small and medium enterprises (MSMEs) is indeed having a positive impact on the target. Both the change in attitude of micro, small and medium business (MSME), methods and habits of micro, small and medium business (MSME) entrepreneurs. With the policy of developing micro, small and medium enterprises (MSMEs) in the city of Kendari, it is highly expected to be able to improve the skills and creativity of micro, small and medium enterprises (MSMEs), but also of course it is expected to be able to increase market access for products of business actors micro, small and medium enterprises (MSMEs) that have been produced as well as towards increasing access to capital credit for micro, small and medium enterprises (MSMEs). By having a good impact on the development of micro, small and medium enterprises (MSMEs), the policy of developing micro, small and medium businesses (MSMEs) can be said to be successfully implemented.

\subsubsection{Enhancing the Skills of Resources of Micro, Small and Medium Enterprises (MSMEs)}

Improving the skills of micro, small and medium enterprises (MSMEs) is the most important thing and must be owned by micro, small and medium businesses (MSMEs) because with good quality skills will lead to increased creativity to support sustainability effort. As such, it is in line with the objectives of the training program held by the Office of Trade, Cooperatives and SMEs of Kendari city to create the skills of MSME actors so that they can have good competitiveness. However, it seems that the purpose of the program has not been realized to its full potential so that it has not had a good impact, this was revealed by informant (B), namely as follows:

"Actually, I once took part in the training held by the Office of Trade, Cooperatives and SMEs in the city of Kendari, if it was not the wrong form of training they held about design and packaging training, but after that the training had no further action, or wanted to provide assistance to MSMEs or 
want to make groups to watch over us, basically there is no good effect in my opinion "(Interview: Friday 16 November 2018).

Furthermore the research informant $(\mathrm{C})$ revealed that

"Previously, I had participated in product design training at a hotel by the Department of Industry, Trade, Cooperatives and SMEs in the city of Kendari, which was held, but I felt there was no change. So in my opinion it's useless to join the training because there are no changes that I feel. Moreover, the training is now gone. I also have never heard of any training information. So I don't think anything has improved. I want to improve. What if training is rarely done, especially I don't often hear information about training because I have never been contacted by an official, usually when I am contacted "(Interview: Saturday 17 November 2018).

The same thing was stated by informant (D) namely:

"I have participated in training a number of times and there have been no changes that I felt, just examples such as how to make the design of patchouli processed products, how do I know to make a packaging design while I do not know to open an application that is loved by employees of the Department of Trade, Cooperatives and SMEs Kendari city. I find it interesting how to maintain the quality of the product all delivered during the training but the training is only done once so that after training tomorrow it forgets how "(Interview: Saturday 17 November 2018).

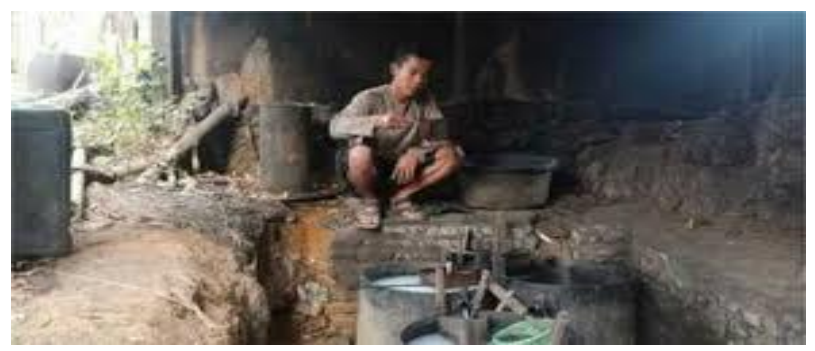

Figure 4.8 Researcher interviews with patchouli oil business actors (2018)

Vol. 28, No. 01 April 2020

(C) Centre for Indonesian Accounting and Management Research Postgraduate Program, Brawijaya University 
Based on the results of interviews conducted by researchers to several research informants taken based on different districts, as many as 4 people to represent micro, small and medium enterprises (SMEs) in the city of Kendari, illustrate that the implementation of training programs in developing micro businesses, small and medium enterprises (MSMEs) have been carried out by the Department of Commerce, Cooperatives and MSMEs of the city of Kendari and have met the needs of micro, small and medium enterprises (MSMEs). However, in its implementation it has not been implemented properly so that it has not yet given maximum impact to improve the skills of the resources of micro, small and medium enterprises (MSMEs). The services of the Kendari City Office of Trade, Cooperatives and SMEs in E-Government still do not have facilities for micro, small and medium enterprises (MSMEs) in accessing information, so the Kendari City Office of Commerce, Cooperatives and SMEs needs to add these services to facilitate businesses micro, small and medium enterprises (MSMEs) to access information from the Department of Commerce, Cooperatives and MSMEs of the city of Kendari.

\subsubsection{Increasing Market Access Products of micro, small and medium enterprises (MSMEs)}

Access to a broad market expansion makes it so important for SMEs in developing their businesses, because with the vast market information it will have an impact on the sale of products that businesses produce. However, so far this has not been going well as expected of the micro, small and medium enterprises (MSME) entrepreneurs as stated by the research informant (B) as follows:

"Previously I had participated in training organized by the Department of Trade, Cooperatives and SMEs of Kendari city, but there has been no change, the training in product packaging making was not good enough because there were many who participated and the guides were also few, so it was not optimal because the other participants were fighting over each other. be taught. And now I see that there are no more trainings "(Interview: Saturday 17 November 2018).

Furthermore, the informant $(\mathrm{C})$ revealed namely,

"I participated in one training, I was trained to make dodol like my dodol but now there are no more rich trainings 
before. So the training is not continued "(Interview: Saturday 17 November 2018).

The same thing was conveyed by the informant (D) namely,

"I see no changes, because I sell my product in the house. Because I do not know where I want to sell. There is no centralized sales place here, Yes, I see there is no centralized sales place yet. For packaging, it is like what you see, you still use ordinary packaging "(Interview: Sunday 18 November 2018).

Based on the results of interviews obtained from several informants above, it illustrates that the training conducted by the Department of Trade, Cooperatives and SMEs in Kendari City, Kendari City, has not had a good impact on micro, small and medium enterprises (MSMEs) to increase access the market for micro, small and medium enterprises (MSMEs) in the city of Kendari. From the results of this interview the researchers concluded that the shortage of the Kendari City Department of Trade, Cooperatives and MSMEs to expand the market access of micro, small and medium enterprises (MSMEs) products is that there has been no development of a sales center for micro, small and medium enterprises (MSMEs) product sales centers. Likewise, the centralized location for ole-ole products produced by micro, small and medium enterprises (MSMEs). Therefore the Kendari City's Office of Trade, Cooperatives and SMEs need to add these services to develop micro, small and medium enterprises (MSMEs) in selling products that micro, small and medium enterprises (MSMEs) produce.

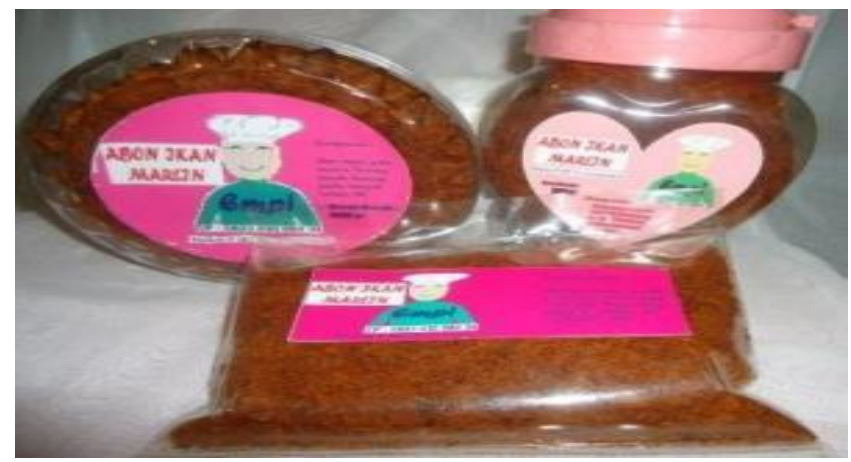

Figure 4.9 Shredded fish packaging (2018)

Vol. 28, No. 01 April 2020

(C) Centre for Indonesian Accounting and Management Research Postgraduate Program, Brawijaya University 


\subsubsection{Increased Access to Business Capital Loans}

The policies carried out by the Kendari City Office of Trade, Cooperatives and SMEs in the city of Kendari, realized through a training program, are very important to help micro, small and medium enterprises (MSMEs) entrepreneurs. In terms of access to capital credit, it is a problem for MSMEs because so far the training carried out by the Kendari Department of Trade, Cooperatives and MSMEs in helping micro, small and medium enterprises (MSMEs) in obtaining access to capital credit has not been as expected as the results of interviews conducted by researchers to the micro, small and medium enterprises (MSMEs) who became informants in this study of the question how the impact of training conducted by the Office of Trade, Cooperatives and SMEs in the city of Kendari in improving access to capital credit so far in the city of Kendari ? The research informant's answer (B) revealed that, among others;

"I think so far only socialization. I once took part in the socialization of the capital loan at the office of the subdistrict head of office in the clarion hotel. It was also said that there was a KUR fund with easy conditions but still used collateral if we wanted to borrow it. I once tried it at the BRI bank but the KUR fund was just disbursed for a long time I waited for almost 3 months and then it was disbursed. It's good if he facilitates the City of Industry, Trade, Cooperatives and SMEs in Kendari, he facilitates us to borrow capital loans at the bank, maybe I can continue to take, but he said, the employees of the Kendari City Office of Commerce, Cooperatives and SMEs only facilitate the socialization tour only "(Interview: Monday 19 November 2018).

The research informant $(C)$ further revealed that:

"I have heard that there is capital credit information, but it is only for borrowing from banks, then I also need to report financial books, which I know for making financial report books. Indeed during this bookkeeping management training but only for now there is no longer reportedly that training. Only after we join the training there is also no evaluation. We also want to have an evaluation after we take part in training so that there is sustainability but this is not there "(Interview: Monday 19 November 2018). 
The same thing was said by informant (D) namely:

"I have also participated in training in managing financial statement books, only after I participated, there has been no further follow-up until now. So if you want to be said to increase like you don't, the thing is the training is only half a day after that we finish there is no more evaluation of what we want to get, no pity. My time has come to an end "(Interview: Monday 19 November 2018).

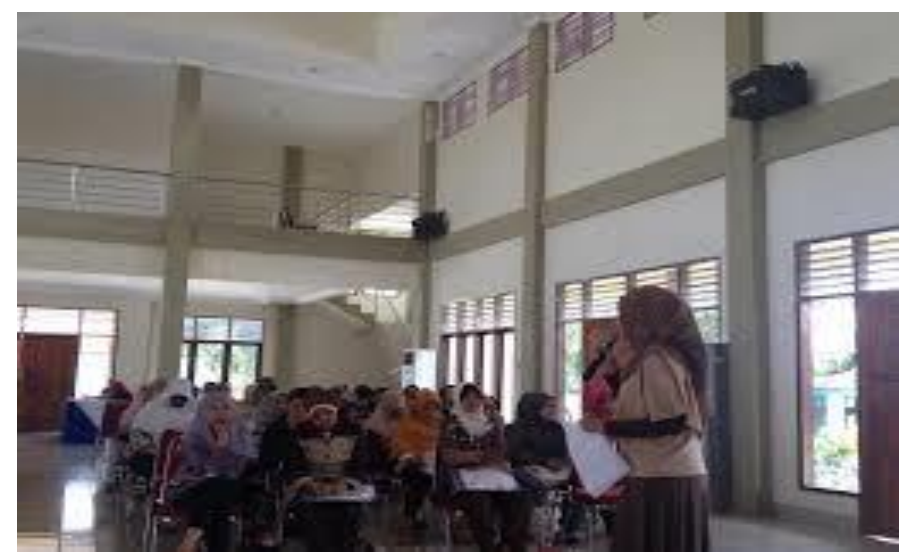

Figure 4.10 Socialization of access to business financing (2018).

Based on the results of interviews conducted by researchers with some of the research informants above it illustrates that the training program conducted by the Office of Commerce, Cooperatives and SMEs in Kendari City has not been able to provide maximum impact in carrying out training. That is because the follow-up (evaluation) of the implementation of the program implemented has not been done well so that to know the success of the implementation of the training can not be seen to what extent the success obtained from the training program conducted by the Department of Commerce, Cooperatives and SMEs in the city of Kendari .

\title{
8. Discussion
}

\subsection{Forms of Micro, Small and Medium Enterprises (MSME) Development Policy in Improving Business Competitiveness}

MSME is a potential business for the development of the economy of Kendari City so that in its implementation it needs to be optimized and explored the potential that exists to increase the economic development of the people of this City. This development will of course be more well developed if

\author{
Vol. 28, No. 01 April 2020 \\ (C) Centre for Indonesian Accounting and Management Research \\ Postgraduate Program, Brawijaya University
}


it is supported by the Kendari City government in providing the facilities needed to support the implementation and progress of the business carried out in order to produce good quality production so that it has competitiveness both nationally and internationally. In this case the role of the Kendari City Office of Trade, Cooperatives and SMEs as an extension of the Regional Government to help overcome the problems that occur in the development of MSMEs in terms of production and processing, access to finance, marketing, human resources, ease of business licensing, as well as design and technology very needed. Therefore, the forms of development policy for UMKM in enhancing the competitiveness of micro, small and medium enterprises (SMEs) in Kendari City are described below namely, as follows:

\subsubsection{Financing and Capital Facilitation Policy}

High interest rates, collateral systems, complicated processes, limited sources of access to capital credit both bank and non-banking are an obstacle for micro, small and medium enterprises (MSMEs) in developing businesses so that they need serious handling. Therefore, with the ease of obtaining access to business capital loans is a solution to the problem of MSME financing to be more developed and advanced.

\section{a) Provision of Access to Kendari City MSMEs in Financing Sources}

Micro, small and medium enterprises (MSMEs) in Kendari City generally rely on their own capital in running their businesses given the low accessibility of formal sources of financing. Regarding the granting of access to funding sources, the Kendari City Office of Trade, Cooperatives and SMEs has given the community access to initial capital. The funding provided comes from the central government (Ministry of Cooperatives and SMEs) and the Southeast Sulawesi provincial government. From the central government, assistance is provided through the LPDB (Revolving Fund Management Agency). The funds are distributed to cooperatives and SMEs who will do capital loans. Whereas from the Southeast Sulawesi provincial government the funds were in the form of social assistance (Social Assistance) and Grants given to cooperatives that had received funding from the government of Rp. 25 million per cooperative for MSME entrepreneurs who wanted to make loans through cooperatives. Budget assistance every year in the form of grants continues to flow to MSMEs both from the APBN and APBD, from 2012 to 2018 the budget reached Rp. 74.4 Billion. The funding assistance can be seen in Table 5.11 Below, namely:

Table 4.11: APBD / APBN Budget Allocation for the MSME sector in Southeast Sulawesi Province 


\begin{tabular}{|c|r|r|r|}
\hline \multirow{2}{*}{ Year } & \multicolumn{2}{|c|}{ Source of funds } & \multirow{2}{*}{$\begin{array}{c}\text { Amount (Million } \\
\text { Rupiah) }\end{array}$} \\
\cline { 2 - 3 } & $\begin{array}{c}\text { APBD (Million } \\
\text { Rupiah) }\end{array}$ & $\begin{array}{c}\text { APBN (Million } \\
\text { Rupiah) }\end{array}$ & 5.020 \\
\hline $\mathbf{2 0 1 2}$ & 1.600 & 3.420 & 4.780 \\
\hline $\mathbf{2 0 1 3}$ & 1.680 & 3.100 & 12.400 \\
\hline $\mathbf{2 0 1 4}$ & 6.200 & 6.200 & 12.186 \\
\hline $\mathbf{2 0 1 5}$ & 3.680 & 8.506 & 12.520 \\
\hline $\mathbf{2 0 1 6}$ & 6.290 & 6.230 & 12.350 \\
\hline $\mathbf{2 0 1 7}$ & 3.850 & 8.500 & 13.189 \\
\hline $\mathbf{2 0 1 8}$ & 10.189 & 3.000 & $\mathbf{7 4 . 4 4 5}$ \\
\hline Total & \multicolumn{2}{|c}{} \\
\hline
\end{tabular}

Source: Southeast Sulawesi Balitbang (2018)

Other support provided by the Kendari City government (Pemkot) to sources of business financing for SMEs is to provide a Regional Public Service Agency (BLUD) to support business capital. The Regional Public Service Agency (BLUD) is a body formed by the Kendari City government (Pemkot) and is directly responsible to the Mayor of Kendari. The Regional Public Service Agency (BLUD) functions as a regional work unit within the scope of the Kendari City government (pemkot) to provide services to the community, especially MSME actors in the form of providing goods or services that are sold without prioritizing or seeking profit. BLUD funds are allocated from the Kendari City budget. The budget allocated from the Kendari City budget for BLUDs is Rp. 750,000,000.

To get a loan from BLUD, customers do not need to use collateral such as land certificates or other forms of collateral such as proposals, but it is sufficient to only have a certain type of business and have a Kendari identity card (KTP). Credit given to SMEs is given without interest, but only pays administration of Rp. 28,000 for every multiple loan transaction of Rp. 500,000 . To get the loan, the customer must form a group of five people. The amount of loan given starts from Rp. 500,000 to Rp. 5,000,000. The mechanism for facilitating financing and capital for BLUDs can be seen in Figure 5.11 as follows: 


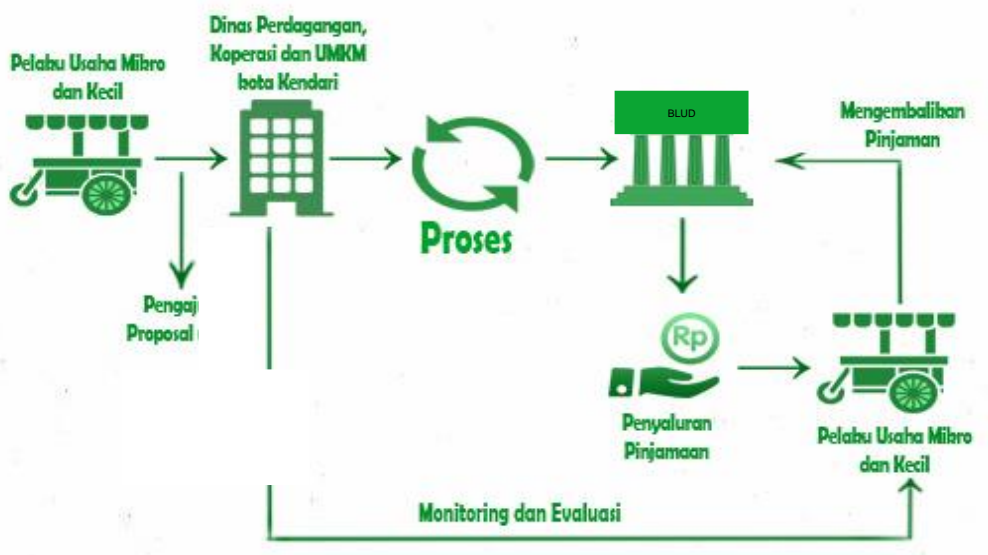

Figure 5.11 Business financing facilitation mechanism in Kendari City BLUD (2018)

Source: Kendari City's Office of Trade, Cooperatives and SMEs (2018), processed

The picture above explains that the flow of financing and capital facilitation undertaken by the Office of Trade, Cooperatives and SMEs in the city of Kendari in an effort to realize the objectives of the policy that has been formulated with the aim of facilitating micro, small and medium business (MSME) entrepreneurs to obtain business capital loans to the Agency Regional General Services (BLUD). In addition to providing facilitation of access to finance at non-bank institutions, the Department of Trade, Cooperatives and SMEs in Kendari City also facilitates MSMEs in banking. The facilitation first held credit socialization for micro, small and medium enterprises (SMEs) in the city of Kendari. The socialization was carried out in collaboration with a number of banks that provided credit services. After the socialization, the training will be carried out by strengthening the capacity of each UMKM business actor by holding trainings organized by the Kendari City Office of Trade, Cooperatives and UMKM in collaboration with the banking sector. Capacity building is more directed at improving the quality of human resources, such as how to manage business financial accounting, business management and production activities.

\section{b) Procurement of Guidance and Training}

Guidance and training conducted by the Department of Commerce, Cooperatives and SMEs in Kendari City is a form of empowerment as motivation or encouragement for the community to hone their abilities and can provide knowledge and skills for people who want to open their own businesses. In overcoming problems faced by MSMEs, the Department of 
Commerce, Cooperatives and MSMEs of Kendari City provides services such as MSME Clinics in collaboration with the Southeast Sulawesi provincial government. In the UMKM Clinic, MSME actors who still have problems in developing their business can consult about plans or business development they run. The limited resources of SMEs in Kendari City in terms of formal education as well as their knowledge and skills greatly affect the management of their business management, so that the business is difficult to develop optimally. In addition, the lack of knowledge about technology will make it difficult for them to increase the competitiveness of the products produced.

Therefore, the importance of the training and training program conducted by the Office of Trade, Cooperatives and SMEs in Kendari City is useful to provide knowledge and skills in developing the businesses they run.

\subsubsection{Product Marketing Support and Promotion Policies}

Marketing is an important element in a business without marketing the products produced will not be known by consumers. Marketing is also an important factor in developing micro, small and medium enterprises (MSMEs). The policy of product marketing support and promotion for SMEs is an urgent matter because with the marketing support policy it can support the development of MSMEs in Kendari City and the products produced can be marketed to a wider market.

\section{a) Increased Product Promotion}

In this case the promotion of product promotion activities carried out by the Office of Trade, Cooperatives and SMEs in the city of Kendari in the form of activities such as bazaars or UMKM exhibitions held in crowded places such as the MTQ pillar and Lippo Plaza during the Southeast Sulawesi anniversary or the anniversary of Kendari City. In addition, this activity is usually held outside the city and even outside the island such as product promotion activities conducted in Surabaya on August 10-14, 2018 at the Grand City Atrium Mall organized by PT Debindo with the name of the Surabaya Great Expo 2018.

This activity also works with the Southeast Sulawesi provincial government to facilitate an area in working with other provinces. The Kendari City Office of Trade, Cooperatives and SMEs undertakes routine product promotion activities every year with different locations. With the diversity of locations and MSME participants from all corners in Indonesia, it is beneficial to expand the MSME marketing network to the international level. 


\section{b) Expansion of Product Marketing}

In this case the Department of Commerce, Cooperatives and UMKM Kendari City has provided a means in marketing products by holding product promotion activities. Nowadays with technological sophistication, marketing can be done using an online system. Because with internet marketing network can be reached overseas. However, this is not well understood by MSMEs because of the low levels of education and science based on e-business. To keep abreast of the times, various trainings provided by the Office of Trade, Cooperatives and SMEs of Kendari City regarding IT were participated by SMEs in Kendari City.

\section{c) Provision of Facilities and Infrastructure}

The Kendari City Department of Trade, Cooperatives and SMEs provides facilities and infrastructure by providing free places as training for people who want to do business. In addition, in marketing, activities such as bazaars or exhibitions for the production of MSMEs are also provided by the Kendari City Department of Trade, Cooperatives and MSMEs in collaboration with MSMEs in other cities. As a means of consultation for people who have problems in their business, namely by providing services KUMKM Clinic in collaboration with the Southeast Sulawesi provincial government. But regarding the facilities for the KUMKM Clinic itself, the Department of Trade, Cooperatives and SMEs in Kendari City did not have such facilities as those in other cities.

In addition, there are no ole-ole sales center facilities provided by the Kendari City Department of Trade, Cooperatives and SMEs.

\subsubsection{Ease of Business Licensing Policy}

\section{a) Provision of Ease of Management of Micro and Small Business Permits through the Camat}

The implementation of business licensing for micro, small and medium enterprises (MSMEs) in the city of Kendari has been delegated to the sub-district where business operators are located so that business licensing is easily accessed by micro, small and medium-sized businesses (MSMEs). Mayor Regulation (perwali) number 37 of 2015 concerning the delegation of authority to implement micro and small business licenses to sub-districts in Kendari City. This Perwali is addressed to the camat as the executor of IUMK in Kendari City. 
Perwali IUMK of Kendari City aims to facilitate access and bring services closer to micro and small businesses. In this case the implementation of the granting of IUMK was delegated to the camat.

In the context of granting IUMK, the Camat conducts data collection and determines the location of MSE actors in their working areas in coordination with the Lurah. The data collection of MSEs is carried out based on the identity of MSEs, the location of MSEs in the district, the type of place of business, the business sector, and the amount of business capital. Whereas determining the location of MSEs is carried out with due regard to public, social, cultural, aesthetic, economic, security, order, health, and / or environmental cleanliness interests. Issuance of IUMK by the camat in the form of a manuscript 1 (one) sheet no later than 1 (one) working day from the date of receipt of the application for registration of IUMK is received completely and correctly. Giving IUMK is not subject to fees, fees, and / or other levies. The PUMK rights are as follows:
a. Carry out business activities;
b. Obtain information and dissemination or notification related to business activities;
c. Getting guidance and facilities in empowerment from the Regional Government;
d. Get easy access to financing to financial institutions, banks or non- banks.


The mechanism for granting licenses to micro, small and medium enterprises (MSMEs) in sub-districts is a way to facilitate micro, small and medium enterprises (MSMEs) to obtain business legality. The mechanism for granting Micro and Small business licenses can be seen in Figure 5.12 below, as follows:

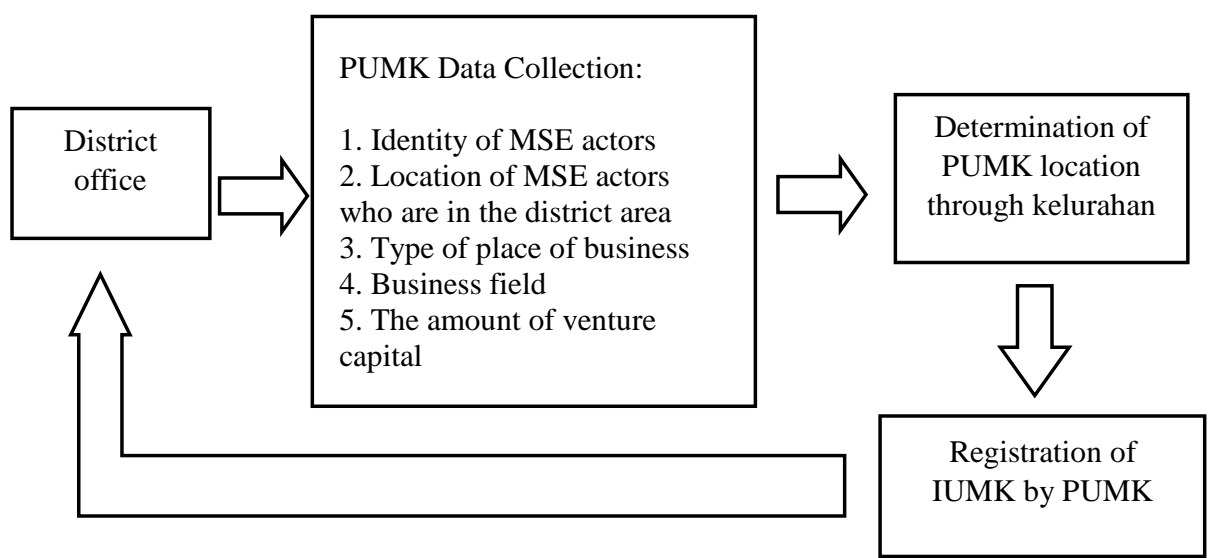

\section{Information:}

UMK = Micro and small business

PUMK = Micro and small businesses

Figure 4.12 Mechanisms for granting micro and small business licenses (MSMEs) in the Source: Department of Commerce, Industry, Cooperatives and SMEs in the city of Kendari 
Based on the picture above, it shows that the data collection was carried out by the sub-district office and then the location determination of PUMK in its area through the kelurahan.

The mechanism for issuing business licenses to micro, small and medium enterprises (MSMEs) in the sub-districts can be seen in Figure 5.12 below, as follows:

\section{Requirements:}

1. Cover letter from RT and RW related to business location

2. Identity Card

3. Family Card

4. Two recent pieces of $4 \times 6$ $\mathrm{cm}$ color photographs

5. Fill out the form

$>$ Name;

$>$ National ID number;

$>$ Telepon Telephone number;

$>$ Address;

$>$ Business activities;

> Usaha Business facilities used;

$>$ Amount of venture capital

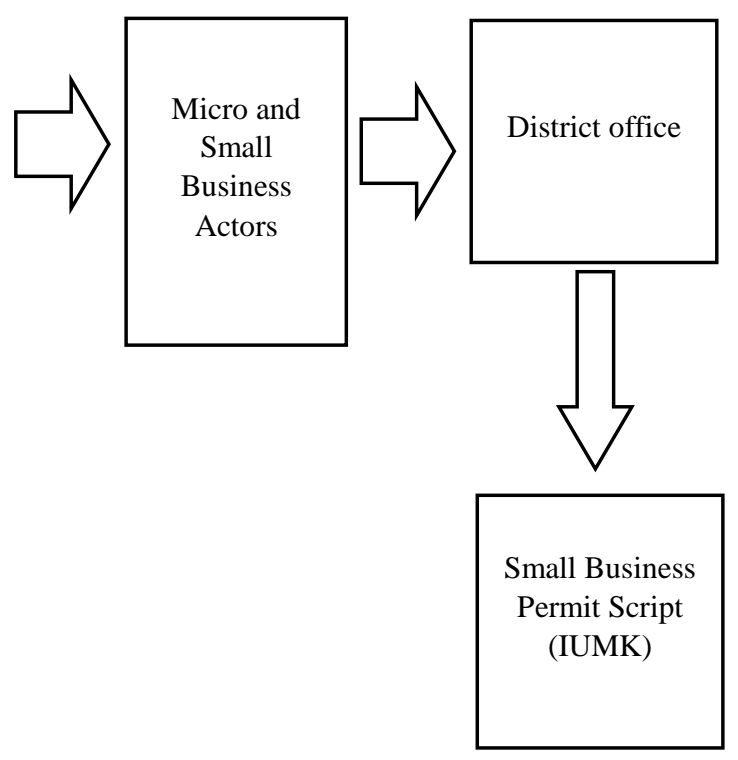

Figure 4.13 Mechanisms for the issuance of Micro and Small Business Permits in the District Source: Department of Commerce, Industry, Cooperatives and SMEs in the city of Kendari

\section{a) Provision of Ease of Management of Medium Business Licenses Through the Application of Pretty Cloud}

SiCanctik Cloud is an acronym for Intelligent Public Integrated Services Licensing Application in the form of a cloud system that can be used by government agencies for free. SiCantik Cloud is a web-based application that 
will be integrated with Online Single Submission (OSS) for business licensing and other services carried out at the One Stop Investment and Integrated Services Office (DPM-PTSP). The legal basis of SiCantik Cloud is Presidential Regulation Number 97 of 2014 concerning the Implementation of Licensing and Non-Licensing by PTSP required to use electronic services (PSE). Related to regional PTSP is explained in Permendagri Number 138 of 2017.

On December 8, 2018 the Mayor of Kendari launched and inaugurated the SiCanctik Cloud application together with the One-Stop Investment and Integrated Services Office (DPM-PTSP) of Kendari City. This application aims to make the community especially in Kendari City medium-sized businesses in the business licensing process. In addition to the SiCantik application, it also provides convenience, namely the Gateway sms service. The purpose of the SMS Gateway is to provide information to the SMEs that the licensing documents have been processed and after the licensing process is completed it will be relayed via SMS Gateway.

\subsubsection{Effectiveness of the Implementation of Micro, Small and Medium Enterprises (MSME) Development Policies in Increasing Business Competitiveness}

Measuring the effectiveness of a program implementation can be seen from the extent to which the program has a real impact on business actors. Programs that have a real impact can be seen from the results of the program produced and of course good results based on well-planned plans too, programs that are very well organized and meticulous certainly quickly impact on improving the skills of business actors, therefore a clear measure is needed in determining an effective program or not. According to Weiss (1972) a measure of program effectiveness can be measured using 5 main elements in the program evaluation model, among others, program objectives, program objectives, program socialization, management and guidance, program monitoring. The description of the six indicators are as follows:

\section{a) Purpose}

In this study, the purpose of the Kendari City Office of Trade, Cooperatives and SMEs in implementing an MSME development policy towards business competitiveness is very clear, this is in line with the vision and mission of the Kendari City Office of Trade, Cooperatives and MSMEs that the program's goal is to improve the welfare of micro, small and medium enterprises (MSMEs) and the creation of Industry, Trade, Cooperatives and MSMEs as the main players in the highly competitive regional economy 
through a program to improve the skills of micro, small and medium businesses (MSMEs) in the city of Kendari.

\section{b) Target}

In implementing this program, the Kendari City Office of Trade, Cooperatives and SMEs as the executor certainly determines the targets of the partnership program, which are micro, small and medium entrepreneurs (MSMEs) who fulfill the requirements. This program must be on target in order to create jobs and welfare for micro, small and medium enterprises (MSMEs). Based on the interview results, the target of this program is clearly focused on micro, small and medium enterprises (MSMEs).

\section{c) Socialization}

The socialization process undertaken by the Kendari City Office of Trade, Cooperatives and SMEs is to involve relevant agencies and interested institutions and micro, small and medium enterprises (MSMEs). However, the socialization that has been conducted so far has not had a positive impact, it was revealed by research informant (B) namely "The socialization that we have carried out so far has not been going well because there is still a sectoral ego between the relevant agencies but if it is to micro businesses, small and medium enterprises (MSMEs) are doing well ".

\section{d) Management and Coaching}

Management and guidance carried out by the Office of Trade, Cooperatives and SMEs in the city of Kendari in developing the skills of SMEs in order to have competitiveness can be seen from the accuracy of the processes carried out by the executor in planning, preparing funds, channeling, fostering and reporting program funds. These elements are believed to be able to see the extent of the successful management and guidance carried out by the policy implementers.

\subsubsection{Impact of Implementing Micro, Small and Medium Enterprises (MSME) Development Policies in Improving Business Competitiveness}

In this study the researchers gave the results obtained about the impact of the program carried out by the Office of Trade, Cooperatives and SMEs in the city of Kendari on three indicators namely increasing the skills of micro, small and medium enterprise (MSME) entrepreneurs, market access for micro, small business products and medium (MSME) as well as access to capital credit for micro, small and medium business (MSME).

Vol. 28, No. 01 April 2020

(C) Centre for Indonesian Accounting and Management Research Postgraduate Program, Brawijaya University 


\section{a) Improving the Skills of Micro, Small and Medium Enterprises (MSME) Business Resources}

Management of human resources (HR) is needed to improve the quality of human resources that exist in every company. Therefore, the purpose of organizing the training conducted by the Office of Trade, Cooperatives and SMEs in the city of Kendari is none other than to realize micro and small businesses (MSMEs) that are able to be competitive in the Kendari city area. However, this study found that the training programs conducted by the Department of Trade, Cooperatives and SMEs in the city of Kendari have not been able to improve the skills of micro, small and medium business (MSME) entrepreneurs so that they have competitiveness. From some interviews found by researchers, it can be seen that the implementation of training programs conducted by the Department of Trade, Cooperatives and SMEs in Kendari City has not had a good impact on improving the skills of micro, small and medium-sized businesses (MSMEs), such as in terms of intellectual intelligence where this intellectual intelligence is the ability needed to understand the material that has been given. For example in making product packaging, researchers found from interviews that micro, small and medium enterprises (MSMEs) after participating in the training had not felt any changes. Like how to make innovative product packaging designs, it is also lacking. This is because the materials provided by the Kendari City Department of Trade, Cooperatives and SMEs tend to be difficult to understand for micro, small and medium enterprises (MSMEs), for example how to operate a product packaging design application, many researchers still find that micro businesses, small and medium enterprises (MSMEs) are still having difficulty using it. Therefore, improving the quality of human resources (HR) is needed to improve the capabilities of the SMEs so that they are able to have competitiveness.

\section{b) Increased Market Access}

One of the problems that is often faced by micro and small businesses (MSMEs) is financial problems, because capital for micro and small businesses (MSMEs) is the main requirement in developing businesses. Micro, small and medium enterprises (MSMEs) generally use their own capital in running their businesses, and sometimes they have difficulty in obtaining access to business capital loans in formal sources of financing to develop their businesses. Therefore, the Trade Office, Kendari City Cooperative UMKM as an extension of the Kendari city government in 
carrying out its duties and functions to implement a policy of facilitating access to business capital credit in banks for micro and small businesses (MSMEs) in order to obtain business capital loans through policies policies are realized in the form of training programs. Therefore, the training program conducted by the Department of Industry, Trade, Cooperatives of SMEs in the city of Kendari that has been compiled in the draft strategic plan (Renstra) is expected to have a good impact in improving the ability and skills of micro and small businesses (MSMEs) in in terms of managing business financial accounting reports. But the expectations expected by micro and small and medium enterprises (MSMEs) are not as expected. As in this study the researchers found that training conducted by the Department of Industry, Trade, Cooperatives of SMEs in the city of Kendari in an effort to improve the ability to manage business financial accounting has not been able to have a good impact so that the micro and small business operators (MSMEs) find it difficult to obtain credit loans business on formal sources of funding, namely banks. So far the efforts of the Department of Commerce, the Cooperative of SMEs in the city of Kendari in helping micro and small and medium enterprises (MSMEs) in getting access to business capital loans are still limited to socialization while at the stage of providing understanding in managing business financial reports so as to improve the quality of business actor resources micro small and medium enterprises (MSMEs) have not been implemented properly. In addition, researchers also found that the training conducted so far has not had a good impact because the evaluation of the implementation of the training was not carried out by the Department of Commerce, Cooperative of SMEs in the city of Kendari. Therefore, to find out the success of the training implementation, it cannot be seen how far the success that has been obtained by the Office of Trade, Kendari City Cooperative Cooperative in implementing policies to increase access to business capital credit is realized through training programs arranged in the Strategic Plan (Rensta) of the Office Trading, Cooperative UMKM city of Kendari.

\section{Conclusion}

Based on the results of the research and discussion stated earlier, it can be concluded that efforts to develop micro, small and medium enterprises (SMEs) in the city of Kendari in order to have competitiveness so that they can compete, the Kendari city government made several policies. The form of the policy that was made is the first policy of financing and capital facilitation; both product marketing support and promotion policies; as well as three business licensing ease policies. The program implementation is carried out through training programs. The training programs carried out so far are

Vol. 28, No. 01 April 2020

(C) Centre for Indonesian Accounting and Management Research Postgraduate Program, Brawijaya University 
training in financial management specifications, technical training in packaging and design specifications, technical management in business management and marketing. However, the travel process has not yet had an effective impact because (1) there has been no follow-up (evaluation) on the programs that have been implemented, (2) there are still micro, small and medium business (MSME) entrepreneurs who have not gained understanding after participating in training, (3) the inadequate human resource (HR) skill of the Disperindag of Kendari city, (4) the lack of specialized personnel to provide financial management assistance, and (5) the absence of an ole-by center for products produced by micro businesses, small and medium enterprises (MSMEs). In addition, the training program carried out by the Office of Trade, Cooperatives and SMEs in Kendari City was felt to be ineffective as seen from the program's effectiveness principles which included a) Program Objectives b) Program Objectives c) Program Socialization d) Appropriate Management and Development e) Program Monitoring .

\section{Suggestions}

Based on the results of the research and discussion previously stated, the researcher gives a suggestion that is, the training programs implemented by the Disperindag of the city of Kendari are expected to maximize (1) the contents of the training material, (2) implement a constructive training strategy and system, (3) conduct evaluation in every training conducted, (4) Need to conduct a program to improve the quality of the apparatus of the Office of Trade, Cooperatives and SMEs in the city of Kendari so as to improve the quality of employees in order to understand the task of providing assistance and guidance to micro, small and medium business (MSME), and (5) The need for procurement of facilities and infrastructure, such as centers for ole-ole centers of products produced by micro, small and medium enterprises (MSMEs). 


\section{REFERENCES}

Abor. Joshua. (2010). Issues in SME Development in Ghana and South Africa International Research Journal of Finance and Economics, ISSN 1450-2887 Issue 39 (2010).

Authority, Samodra. (1994). "Evaluation of Business Policy". Jakarta. PT Raja Grafindo Persada.

Creswell, John W. (2015). Qualitative Research \& Research Design. Yogyakarta: Student Library. Effendy, Onong Uchyana, (1989). "Science, Theory, and Philosophy of Communication". Bandung: PT. Citra Aditya Bakti.

Fatih, Al, Andy (2010) Effect of Implementation of Partnership Policies Against Small Business Performance (Study of Small Businesses in Palembang Patronage Pt. Pusri (Persero) Palembang). Doctoral thesis, Padjadjaran University.

Meter, Van, D. S. and H. B. Asher (1973) "Causal analysis: its promise for policy studies."J. Policy Studies 2 (Winter):103-109.

Nugent, Jeffrey B and Seung-Jae Yhee (2002), "Small and Medium

Enterprises in Korea: Achievements, Constraints and Policy Issues", Small

Business Economics 18: 85-119.

Nurjannah, Siti. (2014). Effectiveness of Development Program Implementation Micro, Small and Medium Enterprises Entrepreneurship By the Cooperative Office Pekanbaru City Small and Medium Enterprises. Jom FISIP Volume 1 No. 2. October 2014.

Rusdin. et. al. (2015). Collaboration-Based Micro, Small and Medium Enterprises (Umkm) Empowerment

Model. Management article.

Rusdin (2009). "The role of UMKM is very big in saving

The Nation's Economy ". Wartawarga 20 December 2009, accessed on 10 December 2018. 
Sulistyastuti Ratih Dyah. (2004). The Dynamics of Small and Medium Enterprises (UKM) Analysis of Regional Concentrations of SMEs in Indonesia 1999-2001. Journal of Development Economics.

Susanto, Astrid S (1975). "Public opinion". Bandung: Bina Cipta.

Tambunan, Tulus T.H. (2009). "MSMEs in Indonesia. Bogor. Ghalia Indonesia Ministry of Cooperatives and SMEs.

Tambunan, Tulus (2001) Perekonomian Indonesia: Teori dan Temuan Empiris.

(Jakarta: Ghalia Indonesia.

Tambunan, Tulus (2000), Development of Small Scale Industries during the New

Order Government in Indonesia, Ash gate Publishing Ltd, England.

Tambunan, Tulus T.H. (2002). "Usaha Kecil dan Menengah di Indonesia: Beberapa isu penting”.

Jakarta; Salemba Empat.

Tambunan, Tulus T.H. (2002). "Small and Medium Enterprises in Indonesia: Some important issues".

Jakarta; Salemba Empat

Tambunan, Tulus T.H. (2009). "MSMEs in Indonesia. Bogor. Ghalia Indonesia Ministry of Cooperatives and SMEs.

Tambunan, Tulus. (2010). “Center for Industry, SME and Business Competition Studies”. Jakarta; Tri sakti University.

Urata, Shujiro (2000), Policy Recommendation for SME Promotion in the Republic of Indonesia, JICA, Tokyo.

Waidi. (2006). The Art of Re-engineering Your Mind for Success. Jakarta:Gramedia. 
Warssono, (2010). MSME accounting turned out to be easy to understand and practice. Yogyakarta: Asgar

Chapter.

Wardhani, Susi, Rulyanti, (2012) Analysis of Factors That Affect Competitiveness in the Bangka

Distinctive Food Industry Center in Pangkal Pinang City. Journal of Accounting, University of

Jember.

Wahab, Abdul, Solichin, 1999, From Policy Formation to Policy Implementation, Student Library:

Yogyakarta.

Wardan, Kusuma, Hesti, (2013) "The Role of the Office of Cooperatives and Small and Medium Enterprises

in Empowering Malang Small and Medium Enterprises (Study of the Malang City Office of

Cooperatives and SMEs", Journal of Public Administration (JAP), Vol. 1, No. 2, tth, pp. 214-215

Walsh, M.F. and Lipinski, J. (2009), "The role of the marketing function in small Enterprise

and medium sized enterprises", Journal of Small Business and Development, Vol. 16, No. 4, pp. 569-585.

Weimer, L.D. and Vining R. (1992). Policy Analysis: Concept and Practice. New

Jersey: Printice Hall, Inc.

Westhead, P and D Storey, 1996. Management Training and Small Firm

Performance. Why is the Link So Weak. International Small Business Journal, July, pp. 13-24.

Welch, L. (2006). The other 51 weeks of the year: A marketing handbook for library ans (Rev. ed.). Wagga Wagga, NSW: Centre for Information Studies, Charles Sturt University.

Webb, K. L., and Lambe, C. J., (2007), "Internal multi-channel conflict: an exploratory investigation and conceptual framework”. Industrial Marketing Management, Vol. 36, No. 1, pp. 29-43.

Vol. 28, No. 01 April 2020

(c) Centre for Indonesian Accounting and Management Research

Postgraduate Program, Brawijaya University 
Weiss, (1972) Defines evaluation research, methods for assessing programs effectiveness, Toronto, Englewood Cliff.

Widjaja, Rai, I.G Corporate Law, First Matter, KBI, Jakarta, 2000.

Wilson, Carter A. (2013). Public Policy: Continuity and Change, 2nd edition. Living Crowe, IL: Waveland Press, Inc.

Wilantara and Susilawati. (2016), Strategy and policy for developing MSMEs. PT Refika aditama. Bandung. 
72 Implementation Of Policies For Micro, Small And Medium Enterprises. . . . .

Vol. 28, No. 01 April 2020

(C) Centre for Indonesian Accounting and Management Research Postgraduate Program, Brawijaya University 